\title{
Effect of Different Levels of Nitrogen and Zinc on Growth and Yield of Baby Corn (Zea mays L)
}

\author{
Ritikesh Raj*, Joy Dawson, Ravi Ranjan Kumar, \\ Alok Kumar Verma and Prakhar Maurya \\ Department of Agronomy, Naini Agriculture institute, SHUATS, Prayagraj-211007, \\ Uttar Pradesh, India \\ *Corresponding author
}

\section{Keywords}

Maize, Cereals, Young cob, Good potential

\section{Article Info}

\section{Accepted:}

17 January 2021

Available Online:

10 February 2021

\section{A B S T R A C T}

A field experiment was conducted to determine the effect of different levels of Nitrogen and zinc on growth and yield of baby corn (variety G 5414) the experiment was carried out in RBD with 10 treatments in the zaid season 2020 with the different levels of Nitrogen $(120,140,160 \mathrm{~kg} / \mathrm{ha})$ and zinc $(15,20,25 \mathrm{~kg} / \mathrm{ha})$. the finding of the experiment showed that he maximum growth attribute i.e. plant height $145.77 \mathrm{~cm}$ was in Treatment $7(140 \mathrm{~kg}$ N/ha $+25 \mathrm{~kg}$ Zinc/ha) and the Yield attributes was found maximum in treatment 10 (160 kg N/ha $+25 \mathrm{~kg}$ Zinc/ha) i.e. 2.60 No. of cob/plant, $973.33 \mathrm{~kg} / \mathrm{ha}$ Cob yield, $1633.33 \mathrm{~kg} / \mathrm{ha}$ Stover yield and the Economic of the experiment i.e. Net return (Rs. 178301.5/ha) and B:C (3.74) was also found maximum in Treatment 10 (160kg N/ha $+25 \mathrm{~kg}$ Zinc/ha).

\section{Introduction}

Maize (Zea mays L.) also known as "Queen of Cereals" belongs to family Graminae and is the third most important cereal crop next to rice and wheat and having highest production potential among the cereals for diversification and value addition of maize as well as growth of food processing industries. Maize has a wide range of adaptation and does not need intensive cultivation. Considering these factors, young cob corn has good potential.
Baby corn production, being a recent development has proved an enormously successful venture in countries like Thailand and Taiwan. Attention is now being paid to explore its potential in India, for earning foreign exchange besides higher economic returns to the farmers. Baby corn production being a recent development has proved an enormously successful venture in countries. Baby corn, a novel utilization of maize, is used as a vegetable in many Asian countries. It is used as an ingredient in the preparation of 
many food items. It refers to whole, entirely edible corn of immature cob harvested just before fertilization at the silk emergence stage (Galinat, 1985).

It is dehusked young ear of the female inflorescence of maize plant, harvested at silk emergence before fertilization (Kapoor, 2002). Young cobs are handpicked when the silk length was about 2-4 cm. The criteria for marketable yield were $4.5-10 \mathrm{~cm}$ length and 0.7-1.7 cm diameter of dehusked cobs having a regular row arrangement (Bar-Zur and Sadi, 1990).

Thavaprakash et al., (2005) and Das et al., (2008) reported that $100 \mathrm{~g}$ of baby corn contained $89.1 \mathrm{~g}$ moisture, $0.2 \mathrm{~g}$ fat, $1.9 \mathrm{~g}$ protein, $8.2 \mathrm{mg}$ carbohydrate, $0.06 \mathrm{~g}$ ash, 28.0 $\mathrm{mg}$ calcium, $86.0 \mathrm{mg}$ phosphorus, and 11.0 $\mathrm{mg}$ of ascorbic acid. Zinc is an essential element for plants, animals and human beings. It is startling to find in the 21 st century that an estimated 2 billion people on the planet are zinc deficient.

Zinc deficiency is more prevalent in developing countries of the world. It is required for a number of metabolic processes.

Therefore, $\mathrm{Zn}$ deficiency can result in a number of health problems like diarrhoea, low birth weight, and stunted growth in children (Rivera et al., 2003) Recommended intake of dietary $\mathrm{Zn}$ ranges from 1.1 to $11.2 \mathrm{mg}$ day-1 in children and 3.0-19.0 mg/day in adults. Recent studies indicated that it is possible to increase $\mathrm{Zn}$ concentration in maize grain by either soil $\mathrm{Zn}$ application or seed priming with $\mathrm{Zn}$ in South Asia.

Maize seed priming with $1 \% \mathrm{ZnSO} 4$ not only enhanced plant growth but also increased the final grain yield and seed $\mathrm{Zn}$ contents in plants grown on soil with limited $\mathrm{Zn}$ availability. In this context, the information is not available on comparative performance of the zinc levels and method of application of zinc in baby corn for increased crop productivity and zinc use efficiency.

Hence, the present field study was undertaken to identify the most suitable level and method of application of zinc in baby corn during prerabi season.

Keeping in view of the above the field and laboratory investigation were conducted with the following objectives: 1 . To find out the effect of nutrient on growth and yield of Baby corn and 2. To find out the economics of the Treatments.

\section{Materials and Methods}

The experiment was carried out during Rabi season of 2019-2020 at Crop Research Farm, Department of Agronomy, Naini Agricultural Institute, SHUATS, Prayagraj (U.P.) which is located at $25024^{\prime} 42^{\prime \prime} \mathrm{N}$ latitude, 810 50' 56" E longitude and $98 \mathrm{~m}$ altitude above the mean sea level.

The soil of the experimental field was sandy loam in texture having $\mathrm{pH} \mathrm{7.4,} \mathrm{medium} \mathrm{in}$ available NPK but low in organic carbon i.e. $0.03 \%$.

The experiment was conducted in Randomized Block Design consisting of 10 treatments combinations with 3 replications and was allocated randomly in each replication. The size of each plot is $3 \mathrm{~m} \times 3 \mathrm{~m}$ The experimental crop were raised by using $G$ 5414 which is High yielding variety and recommended for U. P.

\section{Statistical analysis}

The experiment data was collected to analyse statistical by Fishers method of Analysis (ANOVA) as outline by Gomen and Gomez 
(2010). Critical Difference (CD) value was calculated whenever the $F$ test value was found significant at $5 \%$ level.

\section{Results and Discussion}

At 60 DAS (Harvesting) the significant variation in plant height $(145.77 \mathrm{~cm})$ may be the treatment 7 . The increase in plant height may be attributed to better availability of nitrogen at higher levels of its application, resulting in higher plant height, weight/plant and ultimately higher yield Jat et al., (2009) also reported that the plant height of sweet corn was significantly improved with the increase in rate of nitrogen fertilizer.

The maximum No. of cob/plant $(2.6 \mathrm{cob} /$ plant $)$ was found in treatment $10(160 \mathrm{~kg} \mathrm{~N} / \mathrm{ha}+25$ $\mathrm{kg}$ Zinc /ha) which is followed by treatment 7 (2.53 cob/plant)

The increase in cob yield attributes due to application of zinc was caused by higher chlorophyll contents, and this had apparently a positive effect on photosynthetic activity, synthesis of metabolites and growth-regulating substances, oxidation and metabolic activities and ultimately better growth and development of crop, which led to increase in yield attributes of baby corn. The results were in conformity with Thavaprakash et al., (2008) and Hooda et al., 2013

The significant and maximum Cob yield $(973.33 \mathrm{~kg} / \mathrm{ha})$ was found in treatment 10 (160 $\mathrm{kg} \mathrm{N} / \mathrm{ha}+25 \mathrm{~kg}$ Zinc $/ \mathrm{ha}$ ) However Treatment $3(120 \mathrm{~kg} \mathrm{~N} / \mathrm{ha}+20 \mathrm{~kg}$ Zinc $/ \mathrm{ha}), 4(120 \mathrm{~kg}$ $\mathrm{N} / \mathrm{ha}+25 \mathrm{~kg}$ Zinc $/ \mathrm{ha}), 7$ (140 kg N/ha $+25 \mathrm{~kg}$ Zinc /ha) and $9(160 \mathrm{~kg}$ N/ha $+20 \mathrm{~kg}$ Zinc /ha) was found to be at par with treatment 10 .

Yield is an ultimate end product of many yield contributing components, physiological and morphological processes taking place in plants during growth and development (Mona, due to the effect of dose of nutrients and the significant and maximum plant height was found in treatment $7(140 \mathrm{~kg} \mathrm{~N} / \mathrm{ha}+25 \mathrm{~kg}$ Zinc /ha).

However treatment $10(160 \mathrm{~kg} \mathrm{~N} / \mathrm{ha}+25 \mathrm{~kg}$ Zinc/ha)and treatment $4((120 \mathrm{~kg} \mathrm{~N} / \mathrm{ha}+25 \mathrm{~kg}$ Zinc /ha) was found to be at par with 2015).

The increase in yield attributes due to application of zinc was caused by higher chlorophyll contents, and this had apparently a positive effect on photosynthetic activity, synthesis of metabolites and growth-regulating substances, oxidation and metabolic activities and ultimately better growth and development of crop, which led to increase in yield attributes of baby corn. The results were in conformity with Thavaprakash et al., (2008) and Jat et al., (2009)

The Stover yield was found significant and maximum $(1633.33 \mathrm{~kg} / \mathrm{ha})$ in treatment 10 $(160 \mathrm{~kg} \mathrm{~N} / \mathrm{ha}+25 \mathrm{~kg}$ Zinc $/ \mathrm{ha})$ However Treatment 4 (120 kg N/ha $+25 \mathrm{~kg}$ Zinc/ha), 7 $(140 \mathrm{~kg} \mathrm{~N} / \mathrm{ha}+25 \mathrm{~kg}$ Zinc/ha) and $9(160 \mathrm{~kg}$ $\mathrm{N} / \mathrm{ha}+20 \mathrm{~kg}$ Zinc $/ \mathrm{ha}$ ) was found to be at par with treatment 10 .

Increase in green fodder yield might be due to the enhanced translocation of photosynthates with applied zinc, which resulted in higher production of green fodder in the respective levels of nutrient.

Similar results of significantly higher fodder yield with $\mathrm{Zn}$ application was also reported by Thavaprakash et al., (2008) and Bunker et al., (2013)

The Maximum Net return Rs.178301.5/ha was recorded in treatment $10(160 \mathrm{~kg} \mathrm{~N} / \mathrm{ha}+25 \mathrm{~kg}$ Zinc /ha) while The Maximum B:C 3.74 was recorded in treatment $10(160 \mathrm{~kg} \mathrm{~N} / \mathrm{ha}+25 \mathrm{~kg}$ Zinc /ha) (Table 1). 
Table.1 Effect of different levels of nitrogen and zinc on growth and yield of baby corn (zea mays L)

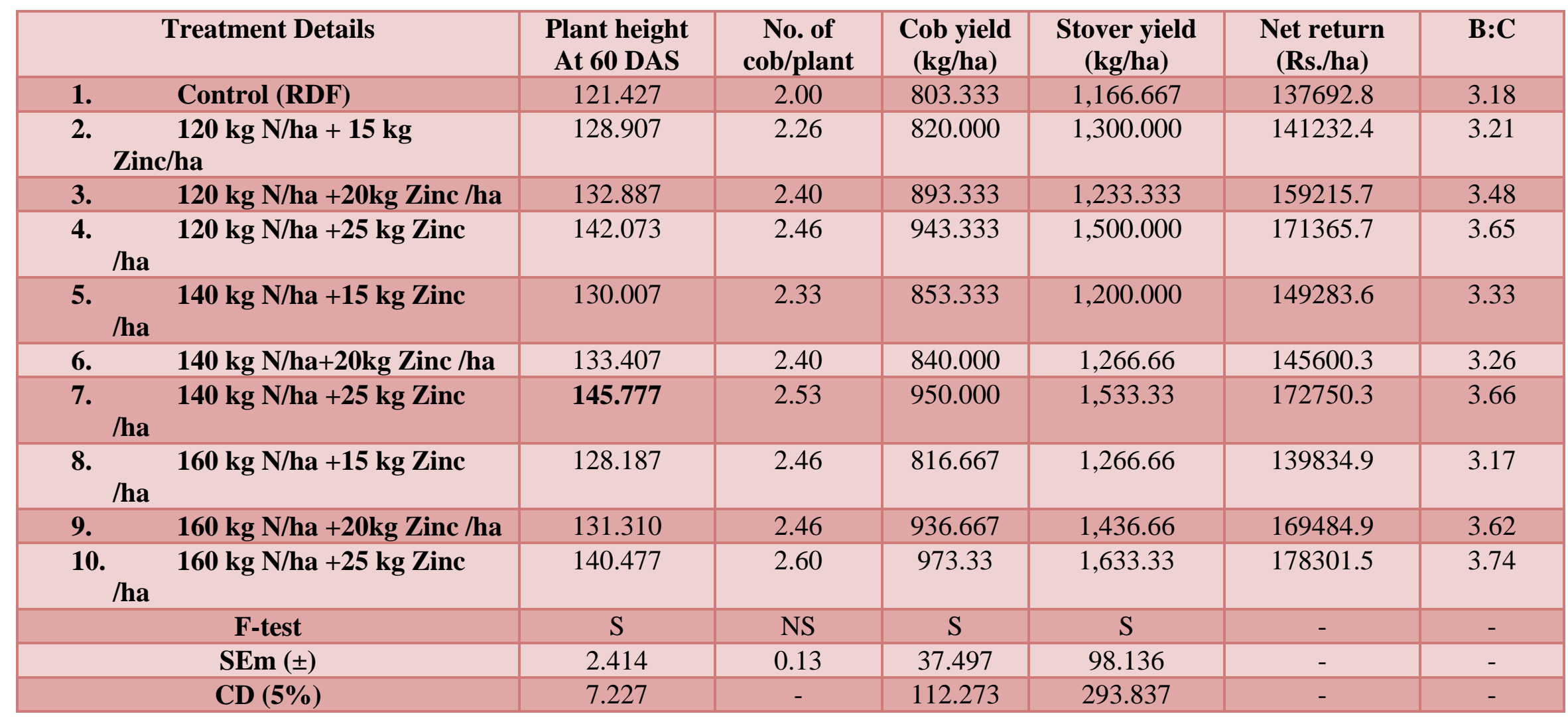




\section{References}

Bunker, M.C., A.M. Patel, M.K. Man and A. Shaukat, 2013. Influence of integrated nutrient management on productivity and quality of single cross hybrid maize (Zea mays L.) Advance Res. J. of Crop Improvement. 4 (1): 54-58. 19 ref

Das SG, Ghosh MD, Bahadur V. 2008. Effect of different levels of nitrogen and crop geometry on the growth, yield and quality of baby corn (Zea mays L.) cv. 'golden baby'. ISHS ActaHorticulturae 809: International Symposium on the Socio-Economic Impact of Modern Vegetable Production Technology in Tropical Asia.

Galinant WC. 1985 Whole ear baby corn, a new way to eat corn. Proceedings of Northeast Corn Improvement Conference. 40:22-27.

Gomez, K.A., Gomez, A.A. 2010. Statistical procedures for agricultural research. $2^{\text {nd }}$ edn. Wiley India Pvt Ltd, India

Hooda, S. and Kawatra, A. 2013. Nutritional evaluation of baby corn. Pub. Emeraid Group Publishing Ltd. Vol. 43 Is: 1, pp.68-73.

Jat V, Tuse BP, Jawale SM, Shaikh AA, Dalavi ND. 2009. Effect of fertilizer levels and dates of sowing on growth and yield of sweet corn (Zea mays saccharata). Journal Maharastra Agricultural University, 34: 109-111.

Kapoor M. Exploit baby corn potential, 2002. Available from http://www.tribuneindia.com/2002/200 20909/ agro.htm\#1

Rivera JA, Hotz C, Gozales-Cossio T, Neufeld L, Garcia-Guerra, A. 2003. The effect of micronutrient deficiencies on child growth: A review of results from community-based supplementation trials. Journal of Nutrition. 133:40104020 .

Thavaprakaash N, Velayudham K, Muthukumar V. B. 2005. Effect of crop geometry, intercropping system and integrated nutrient management practices on productivity of baby corn (Zea mays L.) Based Intercropping Systems. Research Journal of Agricultural and Biological Sciences.; 1(4): 295-302.

Thavaprakaash N, Velayudham K, Muthukumar V. B. 2008. Response of crop geometry, intercropping systems and INM practices on yield and fodder quality of baby corn. Asian J. of Scientific Res.; 1(2): 153-159. 27

\section{How to cite this article:}

Ritikesh Raj, Joy Dawson, Ravi Ranjan Kumar, Alok Kumar Verma and Prakhar Maurya. 2021. Effect of Different Levels of Nitrogen and Zinc on Growth and Yield of Baby Corn (Zea mays L). Int.J.Curr.Microbiol.App.Sci. 10(02): 1977-1981.

doi: https://doi.org/10.20546/ijcmas.2021.1002.237 